\title{
THE STATE OF TEMPORARY EMPLOYMENT SERVICES IN DEMOCRATIC SOUTH AFRICA
}

\author{
by $T$ Nkabinde*
}

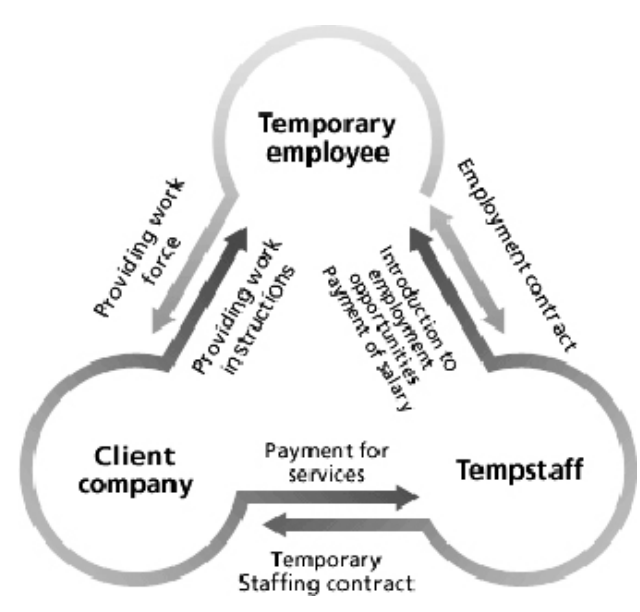

\section{Introduction ${ }^{1}$}

For many years now, South Africa, like many countries has legally recognised labour hiring as a form of employment, through various pieces of legislature. ${ }^{2}$ According to section $198(2)^{3}$ of the Labour Relations $\mathrm{Act}^{4}$ the parties in this tripartite relationship are the temporary employment service is known as the employer, the employee, who is the person who's been contractually procured for his services, and the client, who is the user enterprise that seeks the services of the temporary employment service. This type of employment has been under public and legal scrutiny for a while now

* Thandi Nkabinde, third year LLB student, University of Pretoria.

Image from: www.tempstaff.co.jp/personal/temporary.html (accessed 5 July 2010).

2 See Labour Relations Act 66 of 1995; Employment Equity Act 55 of 1998.

3 Sec 198(2): For the purposes of this Act, a person whose services have been procured for or provided to a client by a temporary employment service is the employee of that temporary employment service, and the temporary employment service is that person's employer.

4 Act 66 of 1995. 
because of malpractice(s) against employees. Trade Unions ${ }^{5}$ have called for the total banning of the operation of temporary employment agencies whereas some organisations ${ }^{6}$ including the Confederation of Associations in the Private Employment Sector (CAPES) have called for codes of conduct that will regulate the industry. The motor industry has recently banned ${ }^{7}$ the operation of temporary employment services in its sector, due to the recent industrial strikes concerning the salaries and wages of employees in the industry. This move has become an exception to section 198. However, will this ban by the motor industry be the beginning of more sectors calling for the ban of temporary employment services in pursuit to being part of the exception? This article will look at the problems faced by temporary employment services in South Africa, the consequences of the lack of enforcement of the laws governing this industry, as well as what South Africa can learn from the international and foreign community.

\section{South Africa}

The main statutory provision that regulates temporary employment services in South Africa is section 198 of the Labour Relations Act. Section 198(1) provides that:

198. Temporary Employment Services

(1) In this section, 'temporary employment services' means any person who, for reward, procures for or provides to a client other persons:

(a) who render services to, or perform work for, the client; and

(b) who are remunerated by the temporary employment service.

This indicates a very peculiar position for every party involved in this relationship. The employer, known as the labour broker, is responsible for all administrative duties concerning the client. The most obvious one being finding workers and those duties concerning their employees, be it the drafting of employment contracts, or the payment of their salaries/wages. The client has the duty to regulate the working environment for the employee in the workplace. The employee is the unlucky one in this whole tripartite relationship because he needs to comply with the instructions of both the client and his employer. Section 198 suggests that there is actually no relationship between the client and the employee even though the

5 Eg. COSATU, NEHAWU, NUMSA, SACCAWU, MEWUSA: (Report of the Portfolio Committee on Labour on the public hearings on Labour Broking, 23 March 2010, at 604 and 607).

6 Eg. APSO, North-West Province SA Organisation, Staffataclick (Report of the Portfolio Committee on Labour on the public hearings on Labour-Broking, 23 March 2010, at 597, 598, 638).

7 Banned officially on 16 September 2010 
client is the one who pays the salary of the employee (indirectly through the labour broker) and the employee works at the premises of the client.

\section{Section 198(4) states that:}

(4) The temporary employment service and the client are jointly and severally liable if the temporary employment service, in respect of any of its employees, contravenes:

(a) a collective agreement concluded in a bargaining council that regulates terms and conditions of employment;

(b) $\quad \ldots$

(c) the Basic Conditions of Employment Act;

(d) $\quad \ldots$

Section 198(4) indicates what both the client and the employer are jointly and severally liable for, this excludes unfair labour practices. I find this particular section problematic because case law ${ }^{8}$ has proved that one of the most unfair labour practices that temporary employees have to deal with is unfair dismissals (which are part of unfair labour practices) at the hands of the client. These unfair dismissals are justified by the employer by using the poor excuse that the employment contracts of the employees have come to an end by operation of law. This in most instances leads to the employee being left unemployed mainly because the dismissal was conducted by the client and there is no legal remedy for the employee because there is no legal relationship between the client and the employee. The employment contract that is concluded between the client and the labour broker in most instances protects both these parties by providing that the employment of the employee will be terminated at the instance of the client. ${ }^{9}$

Temporary employees are one of the most vulnerable groups of employees in South Africa because the usual profile of the average employee is, unskilled, poor, desperate for employment and unknowledgeable as to the tripartite relationship or their statutory and constitutional rights regarding employment. Most of these employees are paid below average wages/salaries, work overtime without any pay ${ }^{10}$ and are not allowed any leave. ${ }^{11}$ These employees do not know that they have a right of recourse against both the client and their employer. This predicament calls for the strengthening of

See NAPE $v$ INTCS Corporate Solutions (Pty) Ltd 20108 BLLR 852 LC where a dismissal that was deemed to be substantively unfair by the court; LAD Brokers (Pty) Ltd v Mandla 200122 ILJ 1813 (LC).

9 n 8 above, 4.

10 Report of the Portfolio Committee on Labour on the public hearings on LabourBroking, 23 March 2010, at 597, 598, 638.

11 Report of the Portfolio Committee on Labour on the public hearings on LabourBroking, 23 March 2010, at 597, 598, 638. 
section 198(4)(c) that makes the client and the employer jointly and severally liable for any contravened provision in the Basic Conditions of Employment Act. ${ }^{12}$ This Act states its purpose to be the advancement of 'economic development and social justice by [interalia] ${ }^{13}$ establishing and enforcing basic conditions of employment'. ${ }^{14}$

Section 198(4)(a) also makes the employer and client jointly and severally liable for any collective bargaining arrangement that has being contravened. In order for the employee to benefit from employee settlements achieved through collective bargaining, their employers must be a part of a registered bargaining council. Even if a temporary employment agency was part of a bargaining council, abiding to the terms of a bargaining council would prove to be a mission because the person who has to ultimately comply with the settlements is the client, and with the client not being the employer of the temporary employee and not registered as a party to a bargaining council, cannot be obligated to adhere to collective bargaining agreements. This is not in line with the right found in section 23(2) of the Constitution which is intended to allow every employee the right to benefit from bargaining council agreements, which is one of the advantages attached to being a member of a trade union.

Another problem that temporary employees face in South Africa is that they are seldom given the same treatment as permanent employees. They are usually the first people to be retrenched during bad economic times and in most instances receive lower wages than their permanent counterparts even though they perform the same job in the work place. The Employment Equity Act ${ }^{15}$ forbids any form of discrimination by the employer and the client to the employee and it also holds the employer and the client jointly and severally liable for any act of discrimination made against the employee. ${ }^{16}$ Section 1 of The Promotion of Equality and Prevention of Unfair Discrimination $\mathrm{Act}^{17}$ defines discrimination as being: ${ }^{18}$

... any act or omission, including a policy, law, rule, practice, condition or situation which directly or indirectly:

(a) imposes burdens, obligations or disadvantage on; or

(b) withholds benefits, opportunities or advantages from,

any person on one or more of the prohibited grounds.

Act 75 of 1997.

My addition.

Sec 2.

Act 55 of 1998.

Sec 57.

Act 4 of 2000 .

Sec 1. 
The Act also defines 'equality' as being inclusive of: ${ }^{19}$

... the full and equal enjoyment of rights and freedoms as contemplated in the Constitution and includes de jure and de facto equality and also equality in terms of outcomes.

Informing temporary workers about available permanent employment opportunities encourages 'employment security' as envisaged by the Constitutional Court in the case of Sidumo and another $v$ Rustenburg Platinum Mine and Others. ${ }^{20}$ The equal treatment of employees (regardless of them being temporary) will also allow them access to collective agreements of a bargaining council and also force employers to not replace permanent employees with temporary workers during industrial strikes and lock-outs. The practice of replacing workers with temporary staff during industrial action is not illegal in Germany; ${ }^{21}$ this is because temporary staff are given the choice of choosing whether or not they want to work for a client who is affected by industrial action. South Africa can learn from this by affording temporary employees with the same kind of arrangement followed by Germany or it can prohibit the employment of temporary employees during strikes and lock-outs. Treating workers equally in the workplace can also minimise the chances of temporary workers being the first amongst all the employees in the workplace to be retrenched. This would mean that workers will be retrenched based on, inter-alia, work performances and not on the fact that they are temporary employees.

\section{Namibian judgement}

Temporary Employment Agencies were banned in its entirety in Namibia following the promulgation of the 2007 Labour Act, in which section $128^{22}$ stipulated that the labour hiring industry was illegal based on the interest of decency and morality. The section 128 provision was challenged in the case of African Personnel Services (Pty) Ltd $v$ Government of the Republic and others. ${ }^{23}$ In this case the applicant (a labour broker) challenged the constitutionality of section 128 citing that the section was not in line with what the Namibian Constitution strived to achieve. The applicant lost the case in the

$\operatorname{Sec} 1$.

200712 BLLR 1097 (CC).

http://www.eurofound.europa.eu/eiro/studies/tn0807019s/de0807019q.htm

(accessed 20-21 October 2009); See also 'Guide to Private Employment Agencies, Regulation, Monitoring and Employment' (pdf file) and 'Private Employment Agencies, temporary agency workers and their contribution to the labour market' (pdf file) (accessed 21 October 2009).

22 Sec 128(4) Insofar as this sec interferes with the fundamental freedoms in Art $21(1)(j)$ of the Namibian Constitution, it is enacted upon the authority of sub art (2) of that Art in that it is required in the interest of decency and morality. 
court $a$ quo and amongst the reasons given by the court were the following: 24

(1) That the contract of employment had only two parties: the employer and the employee;

(2) That labour hire had no legal basis in Namibian common law, which is based on Roman Law;

(3) That the imposition of a third person, i.e. the labour hire company, in the employer-employee (relationship) was unlawful and;

(4) That the right protected by Article 21(1)j of the Republic of Namibia did not include labour hire companies.

It is important to note that the Namibian High Court did not take cognisance of Convention 181 of the International Labour Organization (ILO), which is the Private Employment Agencies Convention. 25 This Convention clearly shows the ILO's stance in supporting the strict regulation of private employment agencies and not the ban thereof.

The loss of the applicant in the High Court resulted in the applicant challenging the court a quo's decision in the Supreme Court of Namibia. The appellant succeeded in his appeal in that the Supreme Court struck down the High Court's decision. The Supreme Court found section 128 to be an unreasonable infringement of the constitutional right to practice any profession, or carry on any occupation, trade or business. The Supreme Court found that the system that was used as a form of contract labour hire by the South West Africa Native Labour Association (SWANLA) was used with the objective of advancing the discriminatory laws of apartheid; those laws the court stated do not apply in Namibia anymore. The court held that there was "no rational relationship between the immoral SWANLA-like contract labour system and the prohibition of agency work on grounds of decency and morality'.26 Unlike the current system in Namibia, with the SWANLA labour hire system, the worker providing the services was known as the employee and the user enterprise as the eventual employer. In addition, the court stated that the labour hiring industry needed strict regulation in order to protect the rights of workers because they were the most exploited in the industry. The court, inter alia, took cognisance of the ILO favouring employment agencies through convention 181 and also indicated that it would be permissible to prohibit employment agencies and clients from employing employees who are contracted temporarily to work permanently for the client. 09-7/NLJ_section_7.pdf (accessed 5 July 2010).

25 Convention 181, 1997 (Namibia is not a member of this convention).

26 Pgs 81 and 82 of official judgment. 
The applicant challenged the constitutionality of section 128 on the protected fundamental right to practice any profession, or carry on any occupation, trade or business. South Africa also has the same constitutionally protected fundamental right; however this right is only available to the citizens of South Africa. According to the South African Citizenship Act, ${ }^{27}$ the status of a citizen is only given to natural persons; this is because the Act only makes provision for the acquisition of citizenship in the Republic through birth, ${ }^{28}$ descent ${ }^{29}$ and naturalisation. ${ }^{30}$ Temporary employment services will be regarded as juristic persons because they are registered businesses. In order for temporary employment services to protect their industry in court, instead of relying on section 22 of the Constitution like the African Personnel Services, they will rely on section 18 of the Constitution, which provides for the right to freedom of association. Their argument will be strengthened further by the fact that South Africa ratified the Freedom of Association and Protection of the Right to Organise Convention on 19 February 1996. The Constitution stipulates that the right to freedom of association is afforded to everyone, and the courts might interpret 'everyone' as being both natural and juristic persons. The right to freedom of association allows people to establish and/or join organisations of their own choice at anytime.

\section{$4 \quad$ International perspectives}

\subsection{C181: Private Employment Agencies Convention ${ }^{31}$}

This Convention further strengthens the points that I have highlighted above. The main factors being that temporary employees must never be denied the right to freedom of association ${ }^{32}$ and the existence of the right to bargain collectively from arrangements ${ }^{33}$ concluded by bargaining councils in order to promote a uniform approach in handling labour matters in a country. The Convention also emphasises that a member state must take the necessary precautions and measures in its country in order to ensure that temporary employees are adequately protected by the malpractices of temporary employment services. They briefly specify that this can be in relation to minimum wages, ${ }^{34}$ access to training ${ }^{35}$ and occupational health and

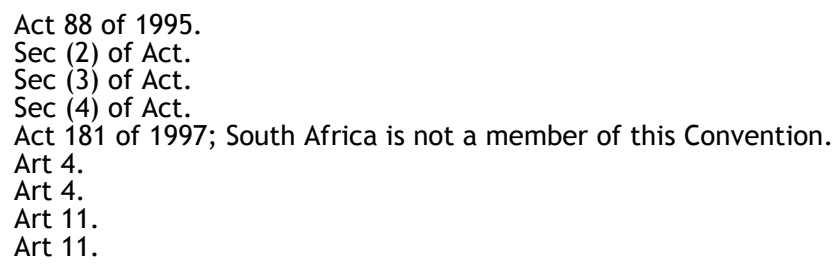


safety in the workplace. ${ }^{36}$ Although South Africa has not ratified this Convention, it can learn what the international standards require from a country that has legalised the operation of labour brokers. It is undeniable that the international community expects temporary employees to be treated in the same way as permanent employees and that there can never be an exception to this rule.

\subsection{Foreign Law}

In the State of Victoria, under the Outworkers (Improved Protection) Act 2003, a worker is empowered to bring legal proceedings against any person that they believe to be their employer. Should that person not in fact be their employer, the respondent to the claim may in turn pass the demand to another party. Adapting this model to the situation of private employment agencies would thus lead to a worker being able to bring proceedings against their presumed employer (the user enterprise), with the user enterprise therefore being liable if it were unable to succeed in showing that the private employment agency ${ }^{37}$ was responsible, or in proceedings intended to enforce such an obligation. 38

The European Directive on Temporary Agency Work (TAW Directive) was adopted in 2008 and it must be implemented by all the members of the European Union. The main objective of the TAW Directive is the equal treatment of all employees in the workplace regardless of whether they are temporary or permanent workers. In addition to the principle of equality, the Directive also states that a temporary employee is to be informed about permanent opportunities in the workplace in order to encourage permanent employment.

\subsection{Proposals}

A substantial number of labour inspectors must be appointed to deal solely with problems related to temporary employment services. They must monitor whether or not temporary employment agencies comply with various laws such as compliance with the Basic Conditions of Employment Act, ${ }^{39}$ whether or not employers are informing workers of their rights in the workplace in order to promote transparency etc. The employment of labour inspectors who will deal solely with issues arising from temporary employment agencies will provide for better implementation of labour laws.

Art 11.

The term used internationally for temporary employment service.

(accessed 17 May 2010) 'RE: Labour law Namibia, Industrial Relations (ILO Pretoria)' E-mail to Erenstein ya Taivo in Windhoek (accessed May 2010). 
Temporary employees must never be used to replace workers who are on strike. Alternatively, these workers must be given the choice to choose whether or not they want to work in an environment that is affected by an industrial action.

Responsible temporary employment agencies and labour inspectors must form a pact with the SAPS that will see the eradication of temporary employment agencies that are operating without any certificate.

Temporary employment agencies must inform their employees about permanent employment opportunities so that temporary employees can be exposed to the same permanent employment opportunities as their counterparts.

The client must also be legally responsible for ascertaining that all employees providing their services and labour to the enterprise have been contracted with their agencies and that the temporary employment agencies they are using are operating legally.

There are two categories of labour inspectors in South Africa, firstly labour inspectors that deal solely with occupational health and safety measures and secondly labour inspectors that deal with labour relations excluding labour practices. The Commission for Conciliation Mediation and Arbitration (CCMA) is the body that has the task to deal with matters concerning unfair labour practices. Most of the employees whose employers are labour brokers complain of unfair labour practices such as refusal of leave from their employers, not getting paid for working overtime, insufficient (or in extreme cases no) payment of wages etc. I would recommend that a department be established within the CCMA that can deal specifically with complaints arising from employees in the temporary employment industry. Employees who have any issues arising from work can go to this department and lay a complaint that will be administered efficiently by people who are knowledgeable about this sector. These employees must be informed of their right to do this if need be.

\section{Conclusion}

The issue of temporary employment agencies in South Africa is a very complex area that requires immediate intervention. Generally employees of these agencies are exploited without any assistance from the government. These employees are the most vulnerable group and their fundamental rights of fair labour practices and just administrative action must be protected. In order to enforce compliance, I believe that there must be stringent implementation methods that will allow for the constant monitoring of these agencies. Imperative intervention is required, but the government must do this with the consultation of various parties such as some of the employees 
themselves, responsible temporary employment agencies and labour organisations such as the National Economic Development and Labour Council (NEDLAC) and the South African Society for Labour Law (SASLAW) so that these regulations are formulated with an understanding of every individual that is affected. I am in favour of not only strict regulations for temporary employment agencies but also for strict regulations of labour inspectors. Labour inspectors need to be monitored so that they do their jobs accurately, effectively and efficiently. South Africa needs to take extensive care in providing decent work to every employee in every workplace as required by the ILO, of which South Africa is a member of. 